\title{
BUCKWHEAT SELECTION IN SOUTH WESTERN FOREST STEPPE CONDITIONS OF UKRAINE
}

\section{Vilchynska Lydmila ${ }^{1}$ \\ Horodyska Olesia ${ }^{2}$}

DOI: http://dx.doi.org/10.30525/978-9934-571-26-8_4

Abstract. The research subject is the buckwheat breeding process in the direction of creating a source material on crop yield and grain quality technological indicators, and by early maturity signs, drought resistance and other economically important features adapted to the southwestern forest-steppe conditions of Ukraine.

The research purpose: on the collection basis of the global gene pool of buckwheat Fagopyrum Mill, to create a new source material on crop yield and technological indicators of grain quality, and early maturity signs and drought resistance, adapted to the southwestern forest-steppe conditions of Ukraine.

Methodology: the metameric features usage of the stalk structure of buckwheat plants is proved and the relationship between the fruiting and branching areas of the shoot for the rapid assessment of promising material on the early maturity basis is established. Donors have been identified for breeding programs on the early maturity basis: Kazanka, Mriia, Veselka, Mih, Solianska, Smuhlianka, Zhniaiarka, № 4013.

The germination method efficiency of buckwheat grains in osmotic solutions has been established to determine its drought resistance. Donors to source material creation on the drought resistance basis are varieties: Kazanka, Mriia, Veselka, Skorostyhla 86, Smuglianka, Kazanka, Alonushka, Veselka.

A buckwheat variety model adapted to the southwestern Forest-Steppe conditions has been developed, an established advantage for the main economically valuable indicators of the newly created varietal samples 7/07.

Created early and drought-resistant buckwheat numbers $(7 / 06,22 / 06$, $23 / 06,24 / 06,25 / 06,4 / 07,5 / 07,6 / 07,15 / 07,16 / 07,33 / 03,219 / 02)$ are

\footnotetext{
${ }^{1} \mathrm{PhD}$ in Agriculture,

Associate Professor of Plant Growing, Selection and Seed Production Department,

Podilskyi State Agrarian and Engineering University, Ukraine

${ }^{2} \mathrm{PhD}$ in Agriculture,

Assistant of Agrochemistry, Chemical and General Biological Disciplines Department,

Podilskyi State Agrarian and Engineering University, Ukraine
} 
characterized in comparison with the standard by high yield and quality of grain, the best economic indicators and are used in breeding programs of the Scientific Research Institute of Crops Research Institute of Podilskyi State Agrarian Engineering University. They were transferred to the National Center of Plant Production Institute nd. a V.Ya. Yuryev of NAAS of Ukraine (NCPPI NAASU) and the Plant Variety Expertise Ukrainian Institute of Plant Varieties Examination (buckwheat of edible Kamianchanka date of submission 18.03. 2016 application № 16008001).

Received author's certificates for buckwheat edible: Malynka, Perlyna Podillia, Kvitneva; The certificate on drought-resistant, like buckwheat sample 7/07, issued by NCPPI NAASU.

\section{Introduction}

One of the most important tasks of modern buckwheat breeding is the source material creation with yield and resistance high level to unfavorable environmental factors, particularly in the context of global warming and its aridity. However, until recently, theoretical studies and directed selection of buckwheat for its early ripeness and drought resistance have not received due attention. Therefore, the study of the existing gene pool from the world collection of buckwheat Fagopyrum Mill, the regularities identification in the formation and inheritance of signs of its early maturity, drought resistance, the creation of a new selection-valuable material adapted to the Forest-Steppe conditions of Ukraine, is an actual task of modern breeding [2, pp. 86-98; 3, pp. 38-42; 5, pp. 136-137; 23, pp. 27-29; 27, pp. 9-10; 34,36 , pp. 20-22; 37, pp. 32-33].

The novelty of topic. For the first time in the southwestern forest-steppe conditions of Ukraine, the morphological characteristics variability of buckwheat plants was revealed, main elements correlation links of seed production were established, namely: the number of inflorescences on the plant with the number of grains and the grain mass from the plant and the height of plants. The genotype-environment interactions and the inheritance rates of plant heights, the number of inflorescences, the amount and mass of grain from the plant, the mass of 1000 grains were studied. The index ratio of morphological indices is determined, which characterizes the early maturity of the variety or the buckwheat form.

The buckwheat varieties model parameters, adapted to the conditions of the southwestern Forest-Steppe were determined for the first time by 


\section{Vilchynska Lydmila, Horodyska Olesia}

the main economic indicators. The express estimation peculiarities of the drought resistance level of buckwheat by the germination method of grains in osmotic solutions are revealed.

A new selection material has been created 33/03, 28/03, 94/01, 219/02, 101/01, 91/01, 83/01, 172/01, 150/01, 89/01, 96/01, 7/06 22/06, 23/06, 24/06, 25/06, 5/07, 7/07, 8/07, 15/07, 24/07, 26/07, which are donors of precocity, drought resistance, increased productivity and the quality of buckwheat seeds [6, pp. 14-19; 18, pp. 207-210].

Practical significance of the obtained results. The new source material (7/07, 8/07, 24/06, 5/07, 15/07, 24/07, 26/07, 19/06) is used in the selection programs of scientific research institutions: the Yaltushkivskii experimental station of the Institute of Bioenergetic cultures and sugar beet NAAN, Ustymivskii experimental station of plant selection named after. V.Ya. Yur'eva NAAN, Subsidiary enterprise pilot farm "Podilske", Ternopil Experimental Station IKHSP NAAN, VP NUBiP of Ukraine, "Zalishchyky Agrarian College named after. E. Khraplyvyi ». Prospective numbers of hybrid origin 7/06, 22/06, 23/06, 24/06, 25/06, 4/07, 5/07, 6/07, 7/07, 15/07 and 16/07 are used in selective programs of the Scientific Research Institute of Crops of Podilskyi State Agrarian and Engineering University, and the best of them 7/07 $($ Kazanka $\times$ Smuhlianka $) \times$ Smuhlianka, 24/07 $\mathrm{SC}_{2} \mathrm{~F}_{4}$ Roksolana $\times$ Kazanka - transferred to the State variety testing as new varieties quality.

The scientific research relevance. The researches were carried out by the authors, they are constituent parts of the state budget subject of the Research Institute of Crops by the registration number 01001U003326, 0107U011751 on the topics: "Selection for high and stable productivity of buckwheat varieties adapted to changing conditions of cultivation and development of energy-saving technologies for their cultivation and harvesting for conditions of the southwestern region of Ukraine" and "Selection and creation of highly productive buckwheat varieties for spring and summer sowingi, the development of technologies their groving conditions for south-western region of Ukraine".

The research purpose: using the global gene pool collection of buckwheat Fagopyrum Mill to create a new source material by hybridization with high yield and technological indicators of grain quality and on the signs of precocity and drought resistance, adapted to the southwestern Forest-Steppe conditions of Ukraine.

To achieve this goal, the following tasks were accomplished: 
- to investigate and characterize the various varieties of buckwheat from the collection of buckwheat Fagopyrum Mill, to select the optimal output forms;

- to conduct simple and repeated crosses and get hybrids of buckwheat $\mathrm{F}_{0}, \mathrm{~F}_{1}, \mathrm{~F}_{2}$;

- establish, on the comparative assessment basis, the economically important indicators of buckwheat grains (early maturity and drought resistance, vegetation period, productivity and technological indicators of grain quality);

- determine the coefficients of inheritance and variation, the phenotypic dominance degree of buckwheat hybrids that are different in terms of output forms;

- to test new varieties of buckwheat in production, to give an economic assessment of their cultivation.

Research conditions: Field research was carried out in the selection crop rotation of the Research Institute of Crops Scientific Research Institute named after. A.S. Alekseeva Podilskyi State Agrarian and Engineering University (SRICC PDATU) and farms and research institutions of Khmelnytskyi, Chernivtsi, Ternopil and Poltava regions for the period 2006-2017.

The soil cover of the experimental field in the overwhelming majority is represented by low-humus, weakly moisture-bearing chernozem. The main groundwater-bearing rock is the carbonate forest and loess-like loam [7, 8].

Methodology. The material for the studies was selected from the collection of the world gene pool RICC PDATU, from which 27 buckwheat varieties Fagopyrum esculentum Moench of different eco-geographical origin, 20 hybrid combinations and 93 hybrids of the first and second saturating crossings were used. The material was studied according to the scheme of the selection process in the selection, control nurseries, as well as the previous and competitive variety testing.

During the hybridization, the heterostylium phenomenon was used: at the beginning of flowering, the defects of plants D (pre-nostalgia) - the type of flowers in the maternal $(+)$ and $\mathrm{K}$ (short-stemmed) - type in the parental (ठ) forms were carried out. In this case, reciprocal crosses were carried out. Simple and complex reverse impregnating crosses were made between the selected numbers from the gene pool collection of the buckwheat genus Fagopyrum Mill and the selection varieties SRICC PDATU [29].

In the breeding seedbed, the numbers were sown for two with four rows areas with a registration area of 1.35 to $2.7 \mathrm{~m}^{2}$. The best hybrid numbers from this seedbed were studied in a control nursery with a registration area of 
$5 \mathrm{~m}^{2}$ in three repetitions. The standard in these nurseries was sown after the corresponding group of hybrids (of the same origin) or through 10 numbers.

Prospective hybrid numbers were studied at the sites of the previous (PS) and competitive (KS) strain tests with a sowing area of $31.5 \mathrm{~m}^{2}$ and accounting of $25 \mathrm{~m}^{2}$ in three (PS) and four (KS) repetitions [29].

The standard in all seedbed is Victoria, which is listed in the Register of Plant Varieties of Ukraine [20].

Bookmarks of experiments, material evaluation, analysis of plants, yield and grain quality were carried out in accordance with the generally accepted methodology of state variety testing. The material was studied under conditions of screen isolation created with the help of the buckwheat tetraploid form. The isolation technique proposed by E.D. Nettevych and M.V. Fesenko and improved by A.S. Alekseeva. The width of the screen bands was $10.8 \mathrm{~m}$ [33, pp. 41-45; 1, pp. 124-141].

Seeding method - wide-row with a row spacing of $45 \mathrm{~cm}$, a cassette seeder SKS-6-10, sowing was carried out on May 12-27.

The following observations, accountings, analyzes and calculations were carried out in the experiments.

1. Phenological observations were carried out according to the State variety testing method with phases fixation of full shoots, budding, flowering, ripening and maturation of $75 \%$ of the fruits. The duration of the vegetative and interphase periods was determined by counting the number of days.

2. The influence of weather conditions on the growth and buckwheat development was analyzed according to the Kamianets-Podilskyi meteorological post.

3. The density of planting was taken into account in the selected areas at the beginning and at the growing season end according to the method developed by V.F. Moiseichenko and V.A. Yeshchenko (1994) [30].

4. The harvest was recorded in a continuous method. The threshing was carried out by the "Sampo-135» combine. The yield was taken into account at $100 \%$ purity and standard moisture. The yield data were processed by the variance analysis method. B.A. Dospekhovym (1985) [22].

5. Analysis of the structure of plants was carried out according to the following parameters: plant height, cm; number of branches, pcs., incl. first order; all: the number of nodes, pcs.; on the main stem; node 1: branching and inflorescence; the number of inflorescences, grains, the grain mass from 
the plant and the mass of 1000 grains. The data obtained are analyzed by the variational statistics method [28].

6. The buckwheat grains quality was determined by such indicators (technological): the mass of 1000 grains, leveling, arillus and nature. The processing of grain quality data was carried out by the method of variance analysis. Analysis of the chemical composition of the grain for the content of trace elements, mycotoxins, pesticides and radionuclides was carried out in the state institution Khmelnytskyi Regional state design and technology center for soil fertility protection and product quality.

7. Buckwheat drought resistance in laboratory conditions was determined by germination of seeds in an osmotic solution of sucrose according to the method proposed by N.N. Kozhushko (1982). The drought resistance (P) indicator was determined by the ratio of the grains sprouting number in a sucrose solution with a concentration of $13.9 \%$, to grains germinating with water [26].

8 . The coefficients of heritability and indicators of the phenotypic dominance degree were determined by the methods described in such literary sources: Zhuchenko A.A. (1980), Griffing B. (1956) [19, pp. 463-493; 25 , pp. 18-20; 28].

\section{The main content of the reserch main results of buckwheat selection}

Buckwheat for Ukrainian has been long traditional national cereal crop, but its homeland is considered Tibet and the highlands of southern China, from where it gradually spread across the planet. So, in 2017 in comparison with 2000 the area of buckwheat field decreased by 3.5 times. But the total grain production decreased only 2.7 times, which indicates an increase in cultivation productivity. The main institutions engaged in breeding buckwheat in our country and whose varieties are included in the "State Register of Plant Varieties Suitable for Distribution in Ukraine" in 2014-2017, include [21]:

- National Science Center "Institute of Agriculture of the National Academy of Agrarian Sciences" (Chabany, Kyiv-Sviatoshinskyi district, Kyiv region), which owns such varieties as: Antharia, Lileia, Nadiina, Olha, Oranta, Ruta, Syn-3/02 Ukrainka, Malva [32]; and TzOV NV MP “Antariia", which is a co-owner of the varieties Syn-3/02, Oranta, Anthariia and owner of the varieties Sofiia and Volia [35];

- The Agriculture Institute of the Northeast of National Academy of Agrarian Sciences of Ukraine (v. Sad, Sumy district, Sumy region) owns 
the following buckwheat varieties listed in the State Register: Ivanna, Krupynka, Selianochka, Slobozhanka, Sumchanka, Yuvileina 100, Yaroslavna [24];

- Scientific Research Institute of Crops named by Alekseeva O.S. Podilskyi State Agrarian and Engineering University (Kamianets-Podilskyi, Khmelnytskyi Region), which owns such buckwheat varieties as Elena, Zelenokvitkova 90, Kara-Dah [31]. Also, the Podilskyi State Agrarian Engineering University together with the Institute of Rice of National Academy of Agrarian Sciences of Ukraine (Antonivka village, Skadovskyi district, Kherson region) is co-owner of the buckwheat grade Stepova [31].

Based on the analysis of data from literature sources of domestic and foreign authors, the buckwheat role in agriculture, the methods for creating a new source material, and the varieties that they obtained are highlighted. The influence of individual factors and characteristics on the vegetative period duration, productivity and yield of buckwheat plants was determined. Proceeding from the analysis, the necessity of buckwheat breeding for early maturity and drought resistance has been established, the conducting research main directions on creating varieties and hybrids with high yield and grain quality adapted to the southwestern Forest-Steppe conditions of Ukraine have been outlined [2, pp. 86-98; 3, pp. 38-42; 5, pp. 136-137; 6, pp. 14-19; 14, pp. 20-21; 18, pp. 207-210; 23, pp. 27-29; $34 ; 36$, pp. 20-22; 37, pp. 32-35].

\section{Buckweat selection on early ripeness and drought resistance}

The use of index indicators to evaluate new material on the basis of early maturity. The vegetation period of buckwheat varieties largely depends on the morphological indices characterizing the shoot bearing zone (ZBP) and shoot branch zone (ZBZ) on the plant. It is established that by using the ratio of indicators, that is, their indexation, it is possible to determine, by an indirect way, the early ripeness of a variety or form. If the ratio of the ZBP indices in the $\mathrm{ZBZ}$ is less than 1, then the plant is probably late-ripening [3, pp. 38-42; 4, pp. 98; 6, pp. 14-19; 15, pp. 33-39].

We conducted a biometric analysis and the main morphological indicators in both the selected parent varieties and the new breeding material. Based on the main morphological features directly related to precocity, the relationship between the fruiting zones and the branching zone of the shoot was determined (Table 1). 
Over the research years, the average number of vegetative nodes in the branching zone of the shoot varied within 4.8 pieces. (Solianska $\times$ Mih) $\times$ Mih; 4.9 pcs. (Veselka $\times$ Alenushka) to 5.9 pcs. (Smuhlianka $\times$ № 4013) $\times$ № 4013. The average number of vegetative nodes on the plant varied within the limits of $11,2-14,1$ pcs. In all hybrid combinations, the ratio between the fruiting and branching branches of the shoot was observed to be greater than one [15, pp. 33-39].

Table 1

Value of ZBP / ZBZ in the best hybrid combinations of buckwheat

\begin{tabular}{|l|c|c|c|}
\hline \multirow{2}{*}{\multicolumn{1}{c|}{ Grade, hybrid }} & \multicolumn{2}{|c|}{$\begin{array}{c}\text { Average number of } \\
\text { nodes, pes }\end{array}$} & \multirow{2}{*}{$\begin{array}{c}\text { Correlat } \\
\text { ZPP/ZBP }\end{array}$} \\
\cline { 2 - 3 } & ZBP & on the plant & \\
\hline Victoriia - St. & 5,8 & 11,4 & 0,97 \\
\hline Skorostyhla 86 $\times$ Solianska & 6,2 & 13,4 & 1,16 \\
\hline$($ Solianska $\times$ Skorostyhla 86$) \times$ Skorostyhla 86 & 6,7 & 13,6 & 1,03 \\
\hline$($ Solianska $\times$ Zhniaiarka) $\times$ Zhniaiarka & 5,5 & 12,2 & 1,22 \\
\hline$($ Smuhlianka $\times$ № 4013) $\times$ № 4013 & 5,9 & 13,6 & 1,31 \\
\hline$($ Mih $\times$ № 4013) & 5,3 & 13,4 & 1,53 \\
\hline Solianska $\times$ Mih) $\times$ Mih & 4,8 & 11,8 & 1,46 \\
\hline (Mih $\times$ Solianska $\times$ Solianska & 5,1 & 14,1 & 1,77 \\
\hline Veselka $\times$ Alonushka & 4,9 & 11,2 & 1,29 \\
\hline
\end{tabular}

Rather high from 1,22-1,77 is the ratio in combinations (Mih $\times$ № 4013), $($ Mih $\times$ Solianska $) \times$ Solianska, $($ Solianska $\times$ Zhniaiarka $) \times$ Zhniaiarka, $($ Smuhlianka $\times$ № 4013) $\times$ № 4013, (Veselka $\times$ Alenushka). This indicates that the new source material on the early maturity basis prevails the original parental forms and can be used in breeding programs as a donor of precocity [9, pp. 91-92].

Express assessment of breeding material for drought resistance.

It has been practically proved that the accuracy of the investigation increases when several estimates give the identical result. In parallel with eye measure assessment in the field, we previously conducted a laboratory assessment of the selection material on the basis of drought resistance by germinating buckwheat seeds in an osmotic solution of sucrose [16, pp. 207-214; 18, pp. 207-210; 27, pp. 9-10].

As a result of the conducted studies it was established that the hybrid combinations obtained from the crossing of varieties Kazanka and Smuhlianka were characterized by high drought resistance (P) 41.2-53.0\%. 
Combinations Smuhlianka $\times$ Kazanka and Kazanka $\times$ Smuhlianka, obtained from the first saturating crossing $\left(\mathrm{SC}_{1}\right)$ for the research years, had relatively high rates of drought resistance $-40.3-47 \%$. This is explained by the fact that the share of parental forms is $1 / 2$ and this attribute was controlled by the action of polymer genes of the Kazanka variety, which indicates its heterozygous conditionality (50.2-30.8\%). In hybrid combinations $($ Smuhlianka $\times$ Kazanka) $\times$ Kazanka and (Kazanka $\times$ Smuhlianka) Smuhlianka received from $\mathrm{SC}_{2}$ in 2007 , the sign was controlled by the combined effect of heterozygotes, from which high drought resistance values $-50.5-47.3 \%$. Under the unfavorable weather conditions influence, the recessive genes of Smuhlianka variety manifested itself, as evidenced by the average indices of this feature [9, pp. 91-92; 16, pp. 207-214; 18, pp. 207-210; 27, pp. 9-10].

The results of the selection material evaluation using the seed germination method in osmotic solutions make it possible to more fully distribute the parental forms and the new buckwheat selection material on the drought resistance basis.

\section{Evaluation of material in kennels breeding process}

The vegetation period of the studied hybrid numbers. We conducted a study of the duration inheritance of the vegetative and interphase periods in the hybrid combinations studied from $\mathrm{SC}_{1}$ and $\mathrm{SC}_{2}$ Inheritance of the vegetation duration in buckwheat hybrids from the first and second saturating crossings was studied for two periods: vegetative (shoots - flowering) and generative (flowering - maturation).

The inheritance nature of the periods studied in the hybrids was significantly different. As a result of the vegetative period inheritance in the buckwheat hybrids from $\mathrm{SC}_{1}$ and $\mathrm{SC}_{2}$, the overwhelming majority of hybrids in 2008 had an intermediate inheritance of $50 \%$. And in the hybrids of $\mathrm{SC}_{1} \mathrm{~F}_{1}$ and $\mathrm{SC}_{1} \mathrm{~F}_{2}$, a tendency to early maturity dominance was observed, namely: $59-64.2 \%$ of hybrids evaded the early ripening parent varieties or reached their level. The number of hybrids bloomed in time, close to late-maturing parental varieties, was smaller (Table 2) [5, pp. 136-137; 9, pp. 91-92; 16, pp. 207-214; 18, pp. 207-210].

The behavior of hybrids about the duration of the generative period was somewhat different. Most of the hybrids $\mathrm{SC}_{1} \mathrm{~F}_{1}$ and $\mathrm{SC}_{1} \mathrm{~F}_{2}$ over the duration of the exceeded period the original parental forms, their num- 
ber was $48.7-70 \%$ of the total number in the experiments [6, pp. 14-19; 10, pp. 12-13; 17, pp. 69-77].

Table 2

Inheritance of the duration of vegetative and interphase periods in buckwheat hybrids from the first and second saturating crosses

\begin{tabular}{|c|c|c|c|c|c|}
\hline \multirow{3}{*}{ Hybridization } & \multirow{3}{*}{ Years } & \multirow{3}{*}{$\begin{array}{c}\text { Number of } \\
\text { hybrids in the } \\
\text { experiment, pcs }\end{array}$} & \multicolumn{3}{|c|}{$\begin{array}{l}\text { Distribution of hybrids by type } \\
\text { of inheritance (in } \% \text { of total) }\end{array}$} \\
\hline & & & \multirow{2}{*}{$\begin{array}{l}\text { intermediate } \\
\text { manifestation } \\
\text { (IM) }\end{array}$} & \multicolumn{2}{|c|}{$\begin{array}{l}\text { the dominance } \\
\text { of high rates }\end{array}$} \\
\hline & & & & $\begin{array}{l}\text { positive } \\
\text { dominance } \\
\text { (PD) }\end{array}$ & $\begin{array}{c}\text { positive } \\
\text { dominance } \\
\text { (PND) }\end{array}$ \\
\hline \multicolumn{6}{|c|}{ Vegetative period } \\
\hline $\mathrm{SC}_{1} \mathrm{~F}_{1}$ & 2007 & 39 & 41 & 41 & 18 \\
\hline $\mathrm{SC}_{1} \mathrm{~F}_{2}$ & 2008 & 14 & 35,8 & 42,7 & 21,5 \\
\hline $\mathrm{SC}_{2} \mathrm{~F}_{1}$ & 2008 & 20 & 50 & 40 & 10 \\
\hline \multicolumn{6}{|c|}{ Generational period } \\
\hline $\mathrm{SC}_{1} \mathrm{~F}_{1}$ & 2007 & 39 & 12,8 & 38,5 & 48,7 \\
\hline $\mathrm{SC}_{1} \mathrm{~F}_{2}$ & 2008 & 14 & 21,5 & 42,7 & 35,8 \\
\hline $\mathrm{SC}_{2} \mathrm{~F}_{1}$ & 2008 & 20 & - & 30 & 70 \\
\hline \multicolumn{6}{|c|}{ Vegetation period } \\
\hline $\mathrm{SC}_{1} \mathrm{~F}_{1}$ & 2007 & 39 & 30,8 & 41 & 28,2 \\
\hline $\mathrm{SC}_{1} \mathrm{~F}_{2}$ & 2008 & 14 & 42,9 & 14,2 & 42,9 \\
\hline $\mathrm{SC}_{2} \mathrm{~F}_{1}$ & 2008 & 20 & 30 & 40 & 30 \\
\hline
\end{tabular}

As the research result, it was found that the total duration of the growing season in hybrids decreased due to the generative period reduction, a greater number of hybrids bent toward the early ripening parent varieties. The number of hybrids that approached late-maturing parental forms was insignificant and amounted to $30 \%$ of the total.

So, according to the growing season duration, it is better to have hybrid combinations (Skorostyhla $86 \times$ Solianska) Solianska $($ Mih $\times$ № 4013) No. 4013, (№ $4013 \times$ Mih) which could be used in breeding programs on the basis of early maturity.

We established a correlation between the main morphological indicators of varieties, the buckwheat family collection samples and the new selection material obtained on their basis. 
A very weak correlation was noted between the height of plants and the number of all branches (027-0.30), the node of the first branching and inflorescence (0.03-0.1). The average correlation was observed between the height of plants and the grain mass from the plant (0.37-0.43), the mass of 1000 grains (0.31-0.35), the number of grains (0.35-042), the branches of the first order (035-0.38). A high correlation was observed between plant height and the number of inflorescences (0.7-0.77), nodes of all (0.6-0.7), nodes on the main stem (0.8-0.87) [13, pp. 68-75] (Table 3).

Table 3

Yield and technological indicators of grain quality of the best hybrid numbers of the breeding seedbed

\begin{tabular}{|c|c|c|c|c|c|c|}
\hline \multirow[b]{2}{*}{$\begin{array}{l}\text { Selection } \\
\text { number }\end{array}$} & \multirow[b]{2}{*}{ Origin } & \multicolumn{2}{|c|}{ Yield, } & \multicolumn{3}{|c|}{$\begin{array}{l}\text { Technological indicators } \\
\text { of grain quality }\end{array}$} \\
\hline & & $\mathbf{g} / \mathbf{m}^{2}$ & \pm to $\mathrm{St}$. & 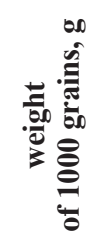 & 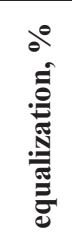 & 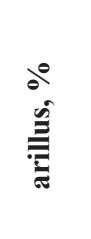 \\
\hline & Victoriia-Standart (St.) & 146,9 & - & 26,9 & 88,2 & 21,9 \\
\hline $33 / 03$ & Ukrainka $\times$ № 4013 & 298,0 & 151,1 & 21,9 & 68,2 & 20,9 \\
\hline $219 / 02$ & № $4013 \times$ Roksolana & 269,0 & 122,1 & 26,9 & 82,6 & 21,9 \\
\hline $94 / 01$ & $\begin{array}{l}\mathrm{F}_{3}[(\text { Veselka } \times \text { Victoriia }) \times \\
\times \text { Victoriia }]\end{array}$ & 285,0 & 138,1 & 26,5 & 76,4 & 22,3 \\
\hline $7 / 06$ & № $4013 \times$ Mih & 171,1 & 24,2 & 27,7 & 92,4 & 21,7 \\
\hline $22 / 06$ & Skorostyhla $86 \times № ~ 4013$ & 213,0 & 66,1 & 29,2 & 74,4 & 21,7 \\
\hline $24 / 06$ & Alenushka $\times$ Veselka & 268,6 & 121,7 & 26,3 & 88,4 & 21,5 \\
\hline $25 / 06$ & Veselka $\times$ Alenushka & 263,3 & 116,4 & 33,7 & 89,7 & 23,5 \\
\hline $15 / 07$ & $\begin{array}{l}(\text { Alenushka } \times \text { Veselka }) \times \\
\times \text { Veselka }\end{array}$ & 245,9 & 99,0 & 28,5 & 94,8 & 22,1 \\
\hline $16 / 07$ & $\begin{array}{l}(\text { Veselka } \times \text { Alenushka }) \times \\
\times \text { Alenushka }\end{array}$ & 257,8 & 119,9 & 32,8 & 88,8 & 23,3 \\
\hline $5 / 07$ & $\begin{array}{l}(\text { Zhniaiarka } \times \text { Solianska }) \times \\
\times \text { Solianska }\end{array}$ & 295,9 & 149,0 & 31,6 & 92,8 & 23,9 \\
\hline $6 / 07$ & $\begin{array}{l}(\text { Solianska } \times \text { Zhniaiarka }) \times \\
\times \text { Zhniaiarka }\end{array}$ & 325,6 & 178,7 & 31,4 & 94,0 & 23,1 \\
\hline $7 / 07$ & $\begin{array}{l}(\text { Kazanka } \times \text { Smuhlianka }) \times \\
\times \text { Smuhlianka }\end{array}$ & 250,4 & 103,5 & 30,7 & 92,0 & 22,5 \\
\hline
\end{tabular}


Yield and technological indicators of grain quality of the best numbers of the seedbed breeding. The criteria for assessing the source material in the breeding seedbed were the yield and grain quality.

Better performance were the numbers of $\mathrm{SC}_{1} \mathrm{~F}_{1}$ 7/06 №. $4013 \times$ Mih, 24/06 Alonushka $\times$ Veselka, 25/06 Veselka $\times$ Alenushka, they exceeded the grade-standard by $24.2-121.7 \mathrm{~g} / \mathrm{m}^{2}$ and are characterized by improved technological quality indicators grain, in particular the grain leveling is higher than the standard by $0.2-5.8 \%$, the mass of 1000 grains is $0.8-6.8 \mathrm{~g}$.

Analyzing the harvest and technological indicators of grain quality, it should be noted that the high numbers had breeding numbers 33/03 Ukrainka $\times$ № 4013, 219/02 № $4013 \times$ Roksolana, 94/01 $\mathrm{F}_{3}[$ (Veselka $\times$ Victoria $) \times$ Victoria], $\mathrm{HC}_{2} \mathrm{~F}_{1}$ 6/07 (Solianska $\times$ Zhniaiarka) $\times$ Zhniaiarka, 4/07 (№ $4013 \times$ Mih) $\times$ Mih, 15/07 (Alonushka $\times$ Veselka) $\times$ Veselka, 16/07 (Veselka $\times$ Alonushka) $\times$ Alonushka, which exceed the standard Victoria on productivity by $31.1-178.7 \mathrm{~g} / \mathrm{m}^{2}$, the leveling off is $0.6-5.8 \%$, the weight of 1000 grains is $1.6-5.9 \mathrm{~g}$, the plavness is $0.2-2 \%$.

Estimation of perspective numbers in the seedbed control. The yield of the samples and the standard variety in the seedbed control varied between 1.34-1.58 $\mathrm{t} / \mathrm{ha}$. The duration of interphase and vegetation period was reduced to 75-90 days compared to the standard.

Hybrid numbers of the seedbed control of 2008 were characterized by a long vegetation period. The beginning of flowering passed on the 23-25th day from sowing, the fruiting of fruits - on the 30-35th day from flowering, ripening - on the thirtieth day from the ripening. Most of the breeding numbers significantly exceeded the Victoria variety in terms of grain quality indicators [16, pp. 207-214] (Table 4).

For the growing season duration, the new selection material was characterized by its reduction in comparison with the Victoria Standard for 7-17 days. Shorter period of the growing season had breeding numbers 24/06, 2/07, 4/07, 7/07, 8/07.

It should be noted that the weather conditions of 2009 were more favorable for the buckwheat plants crop formation. The higher yield and improved technological parameters of grain quality compared to the standard variety Victoria had breeding numbers 6/07, 2/07, 7/07, 16/07, 4/07, 8/07 [15, pp. 33-39].

Preliminary and competitive testing of the best buckwheat numbers. During 2009-2011 years there was a study of prospective numbers selected from the control nursery in the previous (PS) and competitive (KS) strain 


\section{Yield and grain quality of the best buckwheat numbers of the seedbed control}

\begin{tabular}{|c|c|c|c|c|c|c|c|}
\hline \multirow[b]{2}{*}{$\begin{array}{c}\text { Selection } \\
\text { number }\end{array}$} & \multirow[b]{2}{*}{ Origin } & \multirow[b]{2}{*}{$\begin{array}{c}\text { Vegetation } \\
\text { period, } \\
\text { days }\end{array}$} & \multicolumn{2}{|c|}{$\begin{array}{c}\text { Yield } \\
\text { capacity, }\end{array}$} & \multicolumn{3}{|c|}{$\begin{array}{c}\text { Grain Quality } \\
\text { Indicators }\end{array}$} \\
\hline & & & t/ha & \pm to $\mathrm{St}$. & 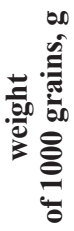 & & 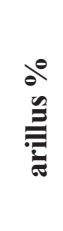 \\
\hline St. & Victoriia-Standart (St.) & 90 & 1,34 & - & 26,1 & 76,5 & 21,9 \\
\hline $4 / 07$ & $($ № $4013 \times$ Mih $) \times$ Mih & 75 & 1,57 & 0,23 & 28,4 & 85,3 & 22,7 \\
\hline $33 / 03$ & Ukrainka $\times$ № 4013 & 94 & 2,77 & 1,43 & 23,0 & 88,6 & 20,9 \\
\hline $219 / 02$ & № $4013 \times$ Roksolana & 94 & 2,18 & 0,84 & 24,6 & 91,0 & 21,3 \\
\hline $2 / 07$ & $($ Solianska $\times$ Mih $) \times$ Mih & 75 & 1,51 & 0,17 & 30,9 & 91,5 & 21,9 \\
\hline $8 / 07$ & $\begin{array}{l}(\text { Smuhlianka } \times \text { Kazanka }) \times \\
\times \text { Kazanka }\end{array}$ & 77 & 1,55 & 0,21 & 29,4 & 90,6 & 21,9 \\
\hline 7/07 & $\begin{array}{l}(\text { Kazanka } \times \text { Smuhlianka }) \times \\
\times \text { Smuhlianka }\end{array}$ & 77 & 1,7 & 0,36 & 30,3 & 92,7 & 22,1 \\
\hline $25 / 06$ & Veselka $\times$ Alonushka & 78 & 1,50 & 0,16 & 30,1 & 89,7 & 22,1 \\
\hline $15 / 07$ & $\begin{array}{l}\text { Альонушка } \times \text { Veselka) } \times \\
\times \text { Veselka }\end{array}$ & 80 & 1,50 & 0,16 & 30,1 & 91,4 & 22,7 \\
\hline $16 / 07$ & $\begin{array}{l}\text { Veselka } \times \text { Alonushka) } \times \\
\times \text { Alonushka }\end{array}$ & 80 & 1,54 & 0,20 & 30,5 & 90,7 & 22,5 \\
\hline $5 / 07$ & $\begin{array}{l}(\text { Zhniaiarka } \times \text { Solianska }) \times \\
\times \text { Solianska }\end{array}$ & 83 & 1,52 & 0,18 & 30,7 & 91,5 & 21,9 \\
\hline $6 / 07$ & $\begin{array}{l}\text { Solianska } \times \text { Zhniaiarka) } \times \\
\times \text { Zhniaiarka }\end{array}$ & 82 & 1,58 & 0,24 & 31,7 & 93,6 & 23,1 \\
\hline & $\mathrm{SSD}_{05}$ & & & 0,14 & & & \\
\hline
\end{tabular}

testing. The main part of them was made up of hybrid material obtained in previous years from crossing varieties of Kazanka, Roksolana, №. 4013, Mih, Veselka, Alenushka, Solianska. In addition to grain quality productivity and technological indicators, these seedbedi determined the survival rate of plants [11, pp. 22; 12, pp. 137-144].

In the PS, ten numbers were observed, their field germination and plant survival varied within $97.9-99.3 \%$.

The overwhelming majority of PS numbers during the research years had approximately the same percent survival of plants - 98.3-98.9 (№ 15/07, 
$8 / 07,2 / 07,8 / 07$ ). Survival in plant numbers 7/07, 2/07, 8/07, 4/07 was observed in comparison with the standard variety.

The lowest percentage of 97.9 plant survival was in breeding number 6/07 (Solianska $\times$ Zhniaiarka) $\times$ Zhniaiarka, and also in numbers $15 / 07($ Veselka $\times$ Alenushka $) \times$ Alenushka $-98.1 \%$. According to the vegetation period,duration it should be noted that the long growing season compared with the standard had breeding numbers 6/07, 2/07, 7/07, 15/07, formed from saturating crosses of varieties Kazanka, Veselka, Alonushka, Smuhlianka, Mih, Solianska. The remaining numbers had the same growing season as the standard. This is explained by the presence in the genotype of hybrids obtained from saturating crossings, the early-ripening variety Kazanka, previously selected from the buckwheat family collection and brought to cross.

Yields of the studied numbers ranged from 1.52-1.96 t/ha, and from the standard $-1.52 \mathrm{t} / \mathrm{ha}$.

For the yield in the PS, Victoria's grade standard was exceeded by 0.20-0.44 t/ha numbers: 7/07 (Kazanka $\times$ Smuhlianka) $\times$ Smuhlianka; 8/07 $($ Smuhlianka $\times$ Kazanka $) \times$ Kazanka; 2/07 (Solianska $\times$ Mih $) \times$ Mih; 4/07 (No. $4013 \times$ Mih) $\times$ Mih; 6/07 (Solianska $\times$ Zhniaiarka $) \times$ Zhniaiarka, (№ $4013 \times$ Ukrainka).

All the investigated breeding numbers were characterized by high technological quality indicators of grain quality - 1000 grains, equalization in comparison with the standard. Due to the higher mass of 1000 grains and evenness, the yield of cereals also increased.

The overwhelming majority of breeding numbers had the high percentage of pluvness and only in numbers $2 / 07$ (Solianska $\times$ Mih) $\times$ Mih this figure was almost at the standard level.

In the competitive variety testing, the numbers obtained by the methods of simple and reverse saturating crossings were studied. The field germination and survival rate of buckwheat plants of the breeding selection numbers in the SC varied within 95.1-99.4\%. Higher in comparison with the standard variety Victoria, the germination capacity, the survival rate of plants and the shorter vegetation period had the numbers 219/02 (№. $4013 \times$ Roksolana), 26 (Kazanka $\times$ Smuhlianka $) \times$ Smuhlianka, $24($ Smuhlianka $\times$ Kazanka) $\times$ Kazanka. Below the standard, field germination and survival of plants had breeding numbers 21 (Solianska $\times$ Zhniaiarka) $\times$ Zhnjarka and 20 (№ $4013 \times$ Mih) $\times$ Mih - by 3.8 and 1.2\%, respectively. In these 
breeding numbers for 1-2 days, the vegetation period was extended in comparison with the standard [11, pp. 22; 12, pp. 137-144].

The yield of selection numbers of the competitive test ranged from 1.64-2.73 t/ha at $1.69 \mathrm{t} / \mathrm{ha}$ to the standard. The best numbers of KS is № 24 (Smuhlianka $\times$ Kazanka $) \times$ Kazanka, № $22($ Solianska $\times$ Mih $) \times$ Mih, № $26($ Kazanka $\times$ Smuhlianka $) \times$ Smuhlianka, 33 (№ $4013 \times$ Ukrainka), obtained from simple saturating crossings, characterized by high in comparison with the standard yield by 0,46-1,04 t/ha and improved technological indicators of grain quality, in particular above the mass of 1000 grains (by 3.7-5.4 g) and equalization (by 11.3-17,4\%) (Table 5).

Таблиця 5

Yield and technological indicators of grain quality of promising buckwheat numbers in competitive variety testing

\begin{tabular}{|c|c|c|c|c|c|c|}
\hline \multirow[b]{2}{*}{$\begin{array}{c}\text { Selection } \\
\text { number }\end{array}$} & \multirow[b]{2}{*}{ Origin } & \multicolumn{2}{|c|}{$\begin{array}{c}\text { Crop } \\
\text { capacity, }\end{array}$} & \multicolumn{3}{|c|}{$\begin{array}{l}\text { Grain Quality } \\
\text { Indicators }\end{array}$} \\
\hline & & t/ha & $\begin{array}{c} \pm \text { to } \\
\text { St.t/ha }\end{array}$ & 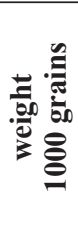 & 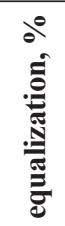 & 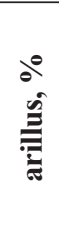 \\
\hline 25 & Victoriia --Standart (St.) & 1,69 & - & 26,0 & 75,4 & 21,7 \\
\hline 33 & (№ $4013 \times$ Ukrainka) & 2,73 & 1,04 & 22,4 & 88,0 & 21,3 \\
\hline 22 & $($ Solianska $\times$ Mih $) \times$ Mih & 2,15 & 0,46 & 29,7 & 86,7 & 23,1 \\
\hline 24 & Smuhlianka $\times$ Kazanka) $\times$ Kazanka & 2,73 & 1,04 & 31,4 & 90,5 & 22,1 \\
\hline 26 & $($ Kazanka $\times$ Smuhlianka $) \times$ Smuhlianka & 2,57 & 0,88 & 30,9 & 92,8 & 22,5 \\
\hline & $\mathrm{SSD}_{\mathrm{Nos}}=$ & & 0,15 & & & \\
\hline
\end{tabular}

Development of buckwheat breed model. Based on the generalization of previous studies and our own results on the creation of selection material, we developed a buckwheat varieties model adapted to the conditions of the southwestern Forest-Steppe. The model is comparatively based on the main economically valuable indicators of the most promising hybrid number 7/07 [18, pp. 207-210] (Table 6).

In comparison with the model the prospective hybrid number is characterized by an average period of vegetation, higher yields, high technological indicators of grain quality (plaviness, flattening, weight of 1000 grains, grain 
nature). According to the chemical composition (protein, fat, starch, fiber content), the seeds of the new variety are at the level of the model (control).

Table 6

Characteristic of the model and new buckwheat variety

\begin{tabular}{|l|c|c|}
\hline \multicolumn{1}{|c|}{ Indexes } & Model & Variety $\mathbf{7 / 0 7}$ \\
\hline Vegetation period, days & $70-90$ & 89 \\
\hline Yield, t/ha & 2,5 & 2,73 \\
\hline $\begin{array}{l}\text { Technological indicators of grain quality: } \\
\text { - weight of 1000 grains, g }\end{array}$ & 28,0 & 31,4 \\
\hline - arillus, \% & $20,1-24,9$ & 22,1 \\
\hline - equalization, \% & $60-90$ & 90,5 \\
\hline - Nature of grain, g/1 & $650-680$ & 665 \\
\hline Content, \%: & & \\
\hline - albumen & $12-14$ & 12,02 \\
\hline - fats & $2-4$ & 2,01 \\
\hline - amylum & 85 & 85 \\
\hline - cellulose & $10-12$ & 11,4 \\
\hline
\end{tabular}

Newly created variety $7 / 07$ is also characterized by improved biochemical indicators, in particular, the content of BEP, the mass fraction of phosphorus, calcium. Approximately the same high economic values had a hybrid sample № 8/07.

\section{We received protection documents for buckwheat varieties:}

1. A. s. with. the plant variety № 09029 Buckwheat edible Malynka / Alekseeva A.S., Vilchinska L.A., Malyna N.N., Ivashchuk P.V.; Application 05002004 (entered in the State Register of Plant Varieties from 2007).

2.A. s. with the plant variety № 110265 Buckwheat edible April/Vilchinska L.A., Malyna N.N., Ivashchuk P.V.; Application 06002001 (entered in the State Register of Plant Varieties, suitable for distribution in Ukraine since 2010).

3. A. s. with the plant variety № 110266 Buckwheat edible Perlyna Podillia / Vilchinska L.A., Malyna N.N., Ivashchuk P.V.; Application 06002002 (entered in the State Register of Plant Varieties from 2011).

4. Certificate of gene pool sample registration of plants in Ukraine № 1300 buckwheat edible population 7/07 dated 26.04. 2013 U.S. Patent No. 0102196. 
In 2016 we transferred to the State variety test the new buckwheat variety edible Kamianchanka (Application No. 16008001 dated 18.03.2016). Based on the preliminary testing results of the new variety in the institutions of the State Expertise, this grade exceeds the average yield of varieties that have passed state registration for the previous five years in the Forest-Steppe zone. The analysis of the field research results on the difference, uniformity and stability (DUS) of this variety in 2017 showed that its uniformity is within the limits of the norm boders.

\section{Testing perspective buckweat numbers in production}

The competitive variety testing perspective numbers were tested in the farms of Khmelnytskyi region - "Myrne", closed joint-stock company, the "Perlyna Podillia" Research and Production Agrofirm, peasant farm enterprise "Zolotoy Kolos", peasant farm enterprise "Lubystoc".

According to the production test results of the numbers obtained by hybridization from the crossing of varieties Kazanka, Roksolana, № 4013, the highest yields and the grain quality best technological indicators had such combinations: (№. $4013 \times$ Ukrainka), (№ $4013 \times$ Roksolana), $($ № $4013 \times$ Kazanka), $($ Kazanka $\times$ Smuglyanka $) \times$ Smuglianka, $($ Smuglianka $\times$ Kazanka $) \times$ Kazanka. Their yield exceeded the Victoria Standard grade by $0.5-1.04 \mathrm{t} / \mathrm{ha}$.

\section{Conclusions}

The article presents theoretical generalization and a new solution to the scientific problem, which consists in creating a new source material in the buckwheat selection by hybridization using buckwheat family samples for yield and technological indicators of grain quality and early maturity signs and drought resistance. Sources of economically useful traits with stable expression are singled out. Genotype-environmental interactions between the plant genotype and the changing conditions of different research years have been studied.

1. It is established variability of morphological characters and the correlation between them in buckwheat plants during cultivation in the southwestern forest-steppe conditions of Ukraine. The boundaries of variation in plant height were $14.5-29.6 \%$, the number of branches of the first order was 29.8-77.9; inflorescence - 47,9-104,1; grains - 60.5-103.6; mass of grain from the plant $-62.5-120.6$; with a mass of 1000 grains $-14.2-31.8 \%$. The 
correlation between the seed productivity main element - the number of inflorescences on the plant - amounted to the number of grains $0.37-0.83 \%$, the grain mass from the plant $-035-0.82 \%$, the plant height $-0.38-0.77 \%$.

2 . It is established that the buckwheat plant precocity depends on the following morphological indices: the first branch node, the first inflorescence node, the average number of vegetative nodes on the plant, the plant height, the nodes on the main stem, the nodes of all, the number of inflorescences and grains. When the ratio of the indices of the fruiting zone to the branching zone of the shoot exceeds 1.0, the vegetative period of buckwheat is, as a rule, reduced.

3. It has been revealed that the varieties can be the sources for obtaining early-ripening forms and varieties in buckwheat breeding: Kazanka, Mriia, Veselka, Mih, Solianska, Smuglianka, Zhniarka, № 4013, selected from the buckwheat family collection.

4. The established efficiency of the rapid assessment of buckwheat breeding material on the drought resistance basis by germination of seeds in osmotic solutions with a sucrose concentration of $13.9 \%$.

5. It is determined that the highest drought resistance in comparison with the parent forms and Victoria variety have hybrid combinations of $515 \mathrm{SC}_{1} \mathrm{~F}_{1}($ Kazanka $\times$ Smuglanka $), 517 \mathrm{SC}_{1} \mathrm{~F}_{1}(($ Kazanka $\times$ Smuhlianka $)$ $\times$ Smuhlianka $), 526 \mathrm{SC}_{1} \mathrm{~F}_{1}(($ Skorostyhla $86 \times$ Solianska $) \times$ Solianska $)$, $535 \mathrm{SC}_{1} \mathrm{~F}_{1}(($ Alonushka $\times$ Veselka $) \times$ Veselka $)$.

6 . Donors create a new source material on the drought resistance basis are the varieties Skorostyhla 86, Smuhlianka, Kazanka, Alonushka, Veselka.

7. The buckwheat numbers $7 / 07,8 / 07,2 / 07,24 / 06$ have a shorter growing period of 5-12 days, a 35.4-47.3\% higher drought tolerance, higher by 0.3-0.7 t/hectare of grain yield compared to standard Victoria variety. The grain of these numbers is characterized by high technological properties, for processing on a cereal, its chemical composition and indicators of food safety meet the regulatory requirements.

8. A model of buckwheat, adapted to the conditions of the southwestern Forest-Steppe, was developed for the main economically valuable indicators. In comparison with the model, grade 7/07 again has a high yield, the best technological parameters of grain quality (weight of 1000 grains, pluvness, alignment, nature), as well as a more balanced biochemical composition.

9. Prospective numbers of hybrid origin are transferred to the National Center for Plant Genetic Resources of Ukraine and are used in the breeding 
programs of the Research Institute of Crops of Podilskyi State Agrarian and Engineering University, and the best of them are 7/07 (Kazanka $\times$ Smuhlianka) $\times$ Smuhlianka, 24/07 $\mathrm{SC}_{2} \mathrm{~F}_{4}$ Roksolana $\times$ Kazanka - are formed to transfer to the state variety testing.

\section{Recommendations for selection practice}

1. Evaluate buckwheat breeding material on the basis of:

- Early maturity by correlation of index morphological indices between fruiting and branching branches, which should be more than one.

- Drought resistance by means of germination of seeds in osmotic solutions of sucrose with a concentration of $13.9 \%$, with an osmotic pressure of $12 \mathrm{~atm}$.

2. To improve the buckwheat grain quality technological parameters as a donor, use the collection sample № 4013 of French selection.

3 . Numbers with economically valuable characteristics $(7 / 06,4 / 07$, $23 / 06,5 / 07,6 / 07,16 / 07,15 / 07,25 / 06,24 / 06,22 / 06)$ used in breeding programs for the creation of more early and buckwheat drought-resistant varieties, with high yield and grain quality.

\section{References:}

1. Alekseeva O. S. (1970) Methody, resultaty i perspective selecziinoi roboty $z$ grechkoi [Methods, results and perspectives of selection work with buckwheat]. Orel: (in Russia).

2. Alekseeva O. S. (2001) Istoria seleczii grechki v Ukraine [History of buckwheat selection in Ukraine]. Kiev: Logos, (in Ukrainian).

3. Balyura V. I. \& Shhagina A. K. (1982) Seleczia grechki na skorostiglost' [Selection of buckwheat for precocity]. Seleczia, cemenovodstvo i technologia viroshyvania grechki [Selection, seed-growing and technology cultivation of buckwheat]. Orel, pp. 38-42.

4. Vilchynska L. A. \& Horodyska O. P. (2008, November) Vpliv skorostiglosti na technologichni pokazniki kachestva zerna grechki [Influence of rapidity on yield and technological parameters of buckwheat grain quality]. Rozvitok naukovich doslidgen 2008: Materialu Chetvertoi Mignarodnya naukovo-praktichnya konferencia [Paper presented at the Development of scientific research 2008: Materials of the Fourth International Scientific and Practical Conference], Poltava: InterGraphics, vol. 8, pp. 98.

5. Vilchynska L. A. \& Horodyska O. P. (2012) Vikoristania kolekzii rody Grechkovi u selekcziunuch programmach NDIKK [Use of the collection of genus Buckwheat in breeding programs RICC PDATU]. Seleczia ta genetika silskogospodarskich roslun: tradizii ta perspiktivi: do 100-richya Selekziuno-geneticheskogo institute - Nazionalnogo zentry nassineznavstva i sortoviivchenia. [Paper presented at the abstracts of the International Scientific Conference. Selection and genetics 


\section{Buckwheat selection in south western forest steppe conditions of Ukraine}

of agricultural plants: traditions and perspectives: to the 100th anniversary of the Selection-Genetic Institute - National Center for Semenology and Sortimental Study], Odessa, pp. 136-137.

6. Vilchynska, L. A. \& orodyska O. P. (2014) Ozinka novogo selekziinogo materialy grechki za oznakoy skorostiglosti [Estimation of new breeding material of buckwheat on the velocity basis]. Chornomorskyi nauchnui gornal accademichnoi nauki [Black sea scientific journal of academic research]. Tbilisi: Georgia, vol. 14, pp. 14-19.

7. Gavrylyuk V. B. Galyschuk V. I. \& Striletskyi O. V. (2010) Grynty Chelnizkoi oblasti. Sychasnui iakisnui stan; zberegenia, vidtvorennia ta polipshenia ih roduchosti [Khmelnytskyi soils. Modern quality condition; preserve, reproduce and improve their fertility]. Kamianets-Podilskyi. (in Ukrainian).

8. Gerenchuk K. I. (1980) Priroda Chelnizkoi oblasti [The nature of Khmelnitsky region]. Lviv: Higher school. (in Ukrainian).

9. Horodyska O. P. \& Vilchynska L. A. (2007) Vliyanie extramalnich usloviu sredy na elementi morfologii rasteniy grechiki [Influence of extreme environmental conditions on elements of the buckwheat plants morphology]. Evropeiska nauka XXI viky - 2007: Materialy II Mignarodnoi nauchno-practicheskoi konferenzii [European Science of the XXI Century-2007: Proceedings of the II International Scientific and Practical Conference]. Dnepropetrovsk: vol. 9, pp. 91-92.

10. Horodyska O. P. (2008) Vplyv nasychyuchich schreshyvan na zminy trivalosti vegetaziunogo periody gibridiv grechki [Influence of saturated crosses to change the duration of the buckwheat hybrids vegetative period]. Naucnay konferenzia: tezy dopovidei Vseukrainskoi nauchno-prakticheskoi konferenzii prisviachenoi 35-richy Naukovo doslidnogo institute krypianich kyltur ta 82-richy z dnia narodgenia vidomogo selekzionera, zasnovnika NDIKK Alekseevoi O. S. [Scientific conference: theses of reports of the All-Ukrainian scientific-practical conference devoted to the 35th anniversary of the Research Institute of Cereal Cultures and the 82nd anniversary of the birth of the famous breeder, the founder of the RICC Alekseeva O. S.]. Kamianets-Podilsky, pp. 12-13.

11. Horodyska O. P. \& Vilchynska L. A. (2008) Urogainiszc ta technologichni pokazniku iakosti zerna hibridiv grechki starshich pokolin' [Yields and technological indicators of grain quality of hybrids of buckwheat elder generations]. Problemu pidvushenia adaptyvnogo potenzialy systemu rosliniztva $v$ zviazky zi zminamy klimaty: tezy dopovidei Mignarodnoi nauchno-prakticheskoi konferenzii [Problems of increasing the adaptive potential of the system of plant growing due to climate change: abstracts of the reports of the International scientific and practical conference]. Bila Tserkva, pp. 22.

12. Horodyska O. P. \& Vilchinskaya L. A. (2008) Stypin fenopypovogo dominyvania y hibridiv grechki starshych pokolin [Degree of phenotypic domination in buckwheat hybrids of older generations]. Selekzia i nasinnuztvo: migvidomchyi tematychnyi naucnyi zbirnuk [Selection and seed production: interagency thematic scientific collection]. Kharkiv: vol. 96, pp. 137-144.

13. Horodyska O. P., Vilchinskaya L. A. (2009) Koefizienty yspadcuvania i variazii okremich morfolochnuch pokaznukiv hibridiv grechki [Coefficients of inheritance and variation of individual morphological indices of buckwheat hybrids]. 
Zbirnik nauchnich praz' Podilskogo dergavnogo agrarno-technichnogo universitety [Collection of scientific works of the Podilskyi State Agrarian and engineering university]. Kamianets-Podilskyi: vol. 17, pp. 68-75.

14. Horodyska O. P. \& Vilchynska L. A. (2009) Vpluv trivalosti vegetazijnogo periody na urogaini ta technologichni pokaznuki iakosti zerna grechki [Influence of the growing season duration on yield and technological indicators of grain buckwheat quality]. Tezy Naukovo-teoretychnoi konferenzii professorsko-a vikladazkogo sklady ta naukovziv, prisviachenoi 90-richy vid dna zasnuvania universitety [Theses of the Scientific-Theoretical Conference of the Faculty and Researchers, dedicated to the 90th anniversary of the University's foundation]. KamianetsPodilskyi, pp. 20-21.

15. Horodyska O. P. \& Vilchynska L. A. (2009) Vpluv nasychyuchich schreshyvan' na skorostiglost', uragainost' ta technologichny pokazniky iakosti zerna grechki [Influence of saturated crossings on speediness, yield and technological parameters of buckwheat grain quality]. Agrobiologia: zbirnik naukovich praz' [Agrobiology: a collection of scientific works]. Bila Tserkva: vol. 1(64), pp. 33-39.

16. Horodyska O. P. \& Vilchynska L. A. (2010) Ozinka selekziinogo materialy grechki za oznakou posychstijkosti [Evaluation of breeding material of buckwheat on the drought resistance basis]. Visnik Lvivskogo Natscionalnjgo Agrarnogo Univesitety: Agronomia [Bulletin of Lviv National Agrarian University: Agronomy]. Lviv: Lviv National Agrarian University, no. 14(2), pp. 207-214.

17. Horodyska O. P. (2012) Vlianie prodolgitelnosti vegetazionogo perioda i nasyshaushich screshyvanyi na prodyktivnost' $i$ technologichni pokozately kachestva zerna grechki [Influence of the vegetation period duration and saturating crosses on productivity and technological indicators of buckwheat grain quality]. Innovazii $v$ nauke: materialy XV Megdynarodnoi zaochnoi nauchno-prakticheskoi konferenzii [Innovations in Science: materials of the XV International Correspondence Scientific and Practical Conference]. Novosibirsk: SibAK, pp. 69-77.

18. Vilchynska L. A. \& Horodyska O. P. (2013) Ischodnyi material v selekzii grechki na zasychoystojchivist' [The initial material in the selection of buckwheat for drought resistance]. Problemy i perspektivy innovazijnogo razvitia mirovogo selskocho hozaijstva [Problems and prospects of innovative development of world agriculture]. Saratov: pp. 207-210.

19. Griffing, B. (1956) [Concept of General and specific combining ability in relation to diallel crossing system]. [Austr. J. Biol. Sci], vol.9, pp. 463-493.

20. Dergavnyi reestr sortiv roslyn, pridatnych dlya poshyrenya v Ukraine na $2017 \mathrm{r}$ [State register of plant varieties, suitable for distribution in Ukraine]. Elekrotronik resurs [Electronic resource]. Available at: (http://www.minagro.gov.ua/ rating/files/r3.pdf), (accessed March 02, 2018)).

21. Dergavna slygba statistika Ukraine. Roslynuztvo Ukraine (2017). [State Statistics Service of Ukraine. Plant Growing of Ukraine]. Elekrotronik resurs [Electronic resource]. - Available at: (http://www.ukrstat.gov.ua), (ccessed March 02, 2018)).

22. Dospexov B. A. (1985) Metodika polovogo opyta (z osnovamy statisticheskoi obrabotki resullatov issledovaniu [Methodology of field experience (with the basics of statistical processing of research results)]. Moscov: Agropromizdat, (in Ukrainian). 


\section{Buckwheat selection in south western forest steppe conditions of Ukraine}

23. Dzhulai N. P. \& Lakhtionova S. O. (2013) Zariza kryp (grechka) [Queen of Greens (Buckwheat)]. Sychasni agrarni technologii [Modern agrarian technologies]. No 8, pp. 27-29.

24. Instityte silskogo hospodarstva Pivnicnogo Schody Natchionalnoi akademii agrarnych nauk Ukraine (2018) [Institute of Agriculture of the North East of National Academy of Agrarian Sciences of Ukraine]. Elekrotronik resurs [Electronic resource]. - Available at: (http://isgps.pp.ua), (accessed March 02, 2018)).

25. Zhuchenko A. A. (2000) Adaptivne semenovodsvo [Adaptive seed production]. Visnuk semenovodsva $v$ SNG [Bulletin of Seed Growing in the SNG]. No 2, pp. $18-20$.

26. Kozhushko N. N. \& Volkova A. M. (1982) Metodichni ykazania. Opredelenie otnositelnoi zasychystojchivosti i garostoikosti obrazcsov zernovich kyltur (psheniza, yachmin') sposobom proroshyvania semyan $v$ rastvorach sacharozu $i$ posle progrevania [Methodical instructions. Determination of relative drought tolerance and heat resistance of grain crops samples (wheat, barley) by seed germination in sucrose solutions and after heating]. Leninhrad, (in Russian).

27. Lakhanov A. P. (1992) Ob ozenke grechyki na zascuchystoichivost' [On the evaluation of buckwheat for drought resistance]. Selekzia i semenovodstvo [Selection and seed-growing], pp. 9-10.

28. Mazer K., \& Jinks J. (1985) Biometrichna henetica [Biometric Genetics]. Moscow: Mir, (in Russian).

29. Volkodav V. V. (Ed.). (2001) Metodika Dergavnogo sortoviprobyvanya silskohospodarskich kyltur (zernovi, krypyani ta zernobobovi kylture) [Technique of the State variety testing of agricultural crops (cereals, grains and legumes)]. Kyiv, (in Ukrainian).

30. Moiseichenko V.F., \& Eshchenko V.O. (1994) Osnovy naukovych doslidjen $v$ agronomii [Fundamentals of Scientific Research in Agronomy]. Kyiv: Higher school, (in Ukrainian).

31. Naukovo-doslidnyu instityte krypyanich kyltur im. Alekseevoi O. S. Podilskogo derjavnogo agrarno technichnogo universitety (2018) [Research Institute of Cereal Crops them. Alekseeva O.S. Podilskyi State Agrarian and Engineering University]. Elekrotronik resurs [Electronic resource]. - Available at: (http://www.pdatu.edu.ua/research-institute-cereals-them-oalekseyevoyi.html), (accessed March 02, 2018)).

32. Nazionalnyu naukoviy zentr "Instityte zemlerobstva Nazionalnoi akademii agrarnuch nauk Ukraine" (2018) [National Scientific Center "Institute of Agriculture of the National Academy of Agrarian Sciences of Ukraine"]. Elekrotronik resurs [Electronic resource]. - Available at: (http:// zemlerobstvo.com/?page_id=398/), (accessed March 02, 2018)).

33. Nettevych E. D. \& Fesenko N. V. (1964) Biologichnyi metod izolyazii obyknovennoi grechki [Biological method of isolation of common buckwheat]. Sekekzia i semenovodstvo [Selection and seed-growing]. No. 2, pp. 41-45.

34. Taranenko L. K. \& Yatsyshen O. L. (2014) Prinzipy, metody i dosagnenya selekzii grechki (Fagopyrum esculentum Moench): monografia [Principles, methods and achievements of buckwheat selection (Fagopyrum esculentum Moench): monograph]. Vinnytsia: LLC Nilan LTD, (in Ukrainian). 
35. TzOV NV MP “Antaria” (2018) [TzOV NV MP “Antariia”]. Elekrotronik resurs [Electronic resource]. - Available at: (http:/antaria.com.ua/en/catalog/ grupa/20), (accessed March 02, 2018)).

36. Fesenko N. V., Koblev S. Yu, \& Martinenko G. E. (1992) Metod sozdania vysokoyrojainich sortov grechki [Method of creating high-yield buckwheat varieties]. Sekekzia i semenovodstvo [Selection and Seed Growing]. No 6, pp. 20-22.

37. Shuvar Ivan. (2011, March) Vona vratye [She will rescue]. Agrobizness sogodni. Gazeta pidpreemziv APK [Agrobusiness today. The newspaper of entrepreneurs APK]. No 6 (205), pp. 32-35. 